\title{
Illustrated checklist of pea clams (Mollusca: Bivalvia: Sphaeriidae) from Nepal
}

\author{
Hasko Nesemann* and Subodh Sharma \\ Aquatic Ecology Centre, Kathmandu University, Dhulikhel, Kavre, NEPAL \\ *To whom correspondence should be addressed.E-mail: hnesemann2000@yahoo.co.in
}

The pea clams (Sphaeriidae) of Nepal are represented by 11 taxa. The highest diversity is found in the mid-altitudinal range between 795 and 1570 masl. Pea clams are poorly represented in the high Himalaya and the Terai. Faunal associations are with the Palaearctic and Oriental regions and with Central Asia. Most pea clams are useful indicator species and, owing to their high abundance and long life span, they are useful in monitoring the water quality of streams.

Key words: Pisidium, Musculium, pea clam, indicator species, Sphaeriidae, Nepal

Himalayan J ournal of Sciences 3(5): 57-65, 2005

Available online at: www.himjsci.com
Received: 22 Feb 2005

Accepted after revision: 12 May 2005
Copyright@ 2005 by Himalayan Association for the Advancement of Science (HimAAS)
At present, 11 taxa (10 species and one subspecies) of pea clams are found in Nepal. Sphaeriids range from 70 to 2750 masl, whereas the Corbiculidae, Unionidae and Amblemidae are mainly restricted to the Terai, below 200 masl elevation. In the mid-altitudes pea clams are a dominant part of the macrozoobenthic communities of running water. Most species are useful indicator organisms for biological water quality. The average life span ranges from one to two or three years. The activity period of two highly specialized taxa is confined to temporary bodies of water and coincides with the 3 to 4 monsoon months of June to Sept. All other species are found throughout the year. All taxa are briefly characterized by figures. Four sphaeriids were not recorded by Nesemann et al. (2001) and represent new records for Nepal. Additional remarks for identification are given.

\section{Methodology}

The study area is situated between the Kali Gandaki and Kosi River Systems $\left(27^{\circ} 35^{\prime}-28^{\circ} 50^{\prime} \mathrm{N}, 8^{\circ} 45^{\prime}-85^{\circ} 40^{\prime}\right.$ E). Field work was carried out from September 2003 to April 2005. Pea clams were collected qualitatively using nets of varying mesh size (1 $\mathrm{mm}, 500 \mu \mathrm{m}, 150 \mu \mathrm{m}$ ), washed where appropriate, and examined under a stereomicroscope. Living specimens were fixed in $70 \%$ ethanol and presumably preserved in the same medium and empty shells were dried. Specimens were deposited in the reference collections of Kathmandu University Museum and the Vienna Natural History Museum (Naturhistorisches Museum Wien), Austria. In order to study seasonal variation, frequent sampling was carried out in selected cites within the middle Mountains of the Central Zone and the Terai region in the Eastern Zone. In making identifications, we relied primarily on a reference collection provided by Dr. Alexei Korniushin, Kiev, Ukraine. Sketches were produced by $\mathrm{H}$. Nesemann. The biological water quality assessment is based on the Nepalese Biotic Score NEPBIOS method, following Sharma (1996). The four water quality classes and their recommended uses are: Class I, excellent, recommended for drinking; Class II, good, drinking possible after treatment; Class
III, fair, hazardous; Class IV, bad, unsuitable for any human use except as a receptacle for sewage.

\section{Descriptions}

\section{Family Sphaeriidae (= in part: Pisidiidae)} Genus Musculium Link, 1807

\section{Musculium indicum (Deshayes, 1854) \\ (= Sphaerium indicum)}

Distribution: Gangetic River basin in northern India (Prashad 1922) and Nepal (Nesemann et al. 2001).

Occurence in Nepal: Common in streams of the upper Bagmati River basin in the KathmanduValley, in the Punyamata Khola, lower Ashi Khola and Cha Khola. Additional populations were found recently in the Phewa Tal and Begnas Tal. Only recorded from 790 masl to 1600 masl.

Ecology: M. indicum lives abundantly in the lower reaches of small or medium-sized midhill streams, where a rich amount of organic matter and detritus is found. It can also be found in small eutrophic ponds and temporary paddy fields. Its occurrence correlates closely with intensive agriculture and natural bodies of shallow water, which are warm in summer. It is largely absent from upstream headwaters, springs and forest streams.

Indicator value: This species tolerates a wider range of organic pollution than all other Sphaeriidae (Sharma 1996). It can be found in spring pools of water quality class I-II, in eutrophic streams of class II and even in critically polluted running waters of class II-III to III, when there is enough oxygen due to high water current and turbulence. It usually lives in association with other Pisidium-species under betamesosaprobic conditions. In more polluted zones (e.g. the Bosan Khola north of Kirtipur and the middle reach of Bishnumati in Kathmandu Valley), $M$. indicum is present in large quantities while other sphaeriids are absent. 


\section{Musculium goshaitanensis nov. spec.}

New to the fauna of Nepal: Musculium goshaitanensis nov. spec. is confined to temporary waterbodies of the Punyamata between Shree Khandapur and Dhulikhel. It is known only from elevations of 1450-1470 masl.

Ecology: Records to date have been confined to paddy fields. It occurs abundantly as the sole sphaeriid or sympatrically with Pisidium clarkeanum dhulikhelensis nov. subspec. Abundance is low and it primarily occurs in dark black mud, which is low in oxygen. Its activity period is June through October. Diapausis of juveniles occurs in soil at a depth of $\geq 50$ $\mathrm{cm}$ from the end of October to mid-June.

Indicator value: Lives in low oxygen conditions sufficient for only a meager level of biological activity.

Description and differential diagnosis: Musculium goshaitanensis nov. spec. differs from Musculium indicum in the following characters: shell more elongated, adult length usually $\geq 10 \mathrm{~mm}$ (8-9.5 $\mathrm{mm}$ in $M$. indicum); caps always present; thin-shelled and fragile, periostracum color gray to dark redbrown with numerous dark concentric growing lines (yellow to gray-blue without dark concentric growing lines in $M$. indicum); inner shell surface dark and glossy (white to yellowish-blue in $M$. indicum); hinge has thin and prolonged anterior and posterior lateral teeth; minute cardinal teeth with short curved triangular C2.

Genus Pisidium Pfeiffer, 1821

Subgenus Jenyns, 1832 (= Casertiana Fagot, 1892)

\section{Pisidium (Euglesa) atkinsonianum Theobald, 1876}

Distribution: Ganga and Brahmaputra River basins. Darjeeling, Sikkim (Prashad 1925), Meghalaya (Subba Rao et al. 1995, coll. of H. N. 2002), Nepal (Nesemann et al. 2001).

Occurrence in Nepal: P. atkinsonianum is known from nine localities in the Kathmandu Valley, including the Bosan Khola (Dudh Pokhari, Simpani), Godavari Khola, Bishnumati Khola and upper Bagmati River in the Shivapuri hills where it ranges from 1300 to 1680 masl. It is abundant from the Punyamata Valley from Nala, Banepa, Dhulikhel to Panauti where it was recorded from twenty-five localities and from three localities of the Roshi Khola downstream from Panauti from 1430 to 1550 masl. The only known populations in the Cha-Khola watershed are in four springs at Khasre and Rohini Bhanjyan at 1785 masl and 2065 masl.

Ecology: P. atkinsonianum is closely related to P. casertanum and replaces the latter species in large parts of the central and eastern Himalaya. It is largely confined to flowing water and occurs in small- to medium-sized streams, being almost absent from forest-streams and stagnant water bodies. Very large forms are found in slightly eutrophic water and agricultural irrigation channels. It is often associated with Musculium indicum in the lower reaches and Pisidium annandale $i$ in the upper reaches of the same streams.

Indicator value: P. atkinsonianum tolerates a wider range of organic pollution than other Pisidium species and is able to exploit habitats rich in detritus and fine organic material. It is usually found in Class I-II to II-III water, indicating mainly betamesosaprobic conditions, it occurs only rarely in Class I environments. It is locally abundant, and very often the dominant bivalve species with densities reaching several hundred individuals per square meter. P. atkinsonianum is therefore a good indicator species for low to moderate pollution.

\section{Pisidium (Euglesa) casertanum Poli, 1791}

Distribution:Widely distributed in the Palaearctic and Nearctic region, it also occurs in some parts of South America, Africa and Australia and is the most widely distributed species of freshwater mollusc in the world (Clarke 1981). In Asia, $P$. casertanum is found in the upper Indus River basin in Kashmir (Prashad 1925, Subba Rao 1989), in China (Tibet) and eastwards to the Amur River basin (Zeissler 1971). In Southeast Asia, Brandt (1974) reported one locality in Thailand.

New to the fauna of Nepal: Kavre District, Banepa, small springstream to the lower Chandeshwari Khola, $0.5 \mathrm{~km}$ SE of Chandeshwari, 8. 1.2005, elevation 1615 masl.

Ecology: The species was found abundantly in a very small natural cold stream in dense mixed Rhododendron forest. The water temperature was $11^{\circ} \mathrm{C}$ on 10th January, 2005. The microhabitat was fine mud and leaf litter in very shallow pools. No other bivalves occur so far upstream. P.casertanum lives in association with the prosobranch gastropod Tricula montana and the potamid crab Himalayapotamon spec. (sensu Brandis and Sharma 2004).

Indicator value: This predominantly holarctic species of temperate regions is known in Nepal only from this uppermost headwater with constant low temperature and no anthropogenic pollution, with Class I water quality.

Remarks: P.casertanum is distinguished from the closely allied P. atkinsonianum by the following characters: small size, maximum length usually 3.0 to $3.7 \mathrm{~mm}$; thick-shelled, surface with fine irregular striations; periostracum yellowish to redbrown in the posterior half; hinge more curved than in $P$. atkinsonianum; anterior and posterior teeth rather thick; cardinal teeth C2 and C3 distinctly curved; umbones more prominent and more shifted posteriorly than in $P$. atkinsonianum.

\section{Subgenus Odhneripisidium Kuiper, 1962}

\section{Pisidium (Odhneripisidium) annandalei Prashad, 1925}

Distribution: Oriental region including some Mediterranean parts of southeast Europe (Zeissler 1971), Sicily, southern Italy and Greece. From Israel to Southeast Asia and India (Subba Rao 1989), Bihar (Prashad 1925), Meghalaya (coll. of H.N. 2002), Nepal (Nesemann et al. 2001), Thailand and Indonesia (Brandt 1974).

Occurrence in Nepal: Two localities in the southwest Kathmandu Valley (Central Zone), Bosan Khola with Dudhpokhari and Simpani, twenty localities in the Punyamata Valley, numerous localities in the Ashi Khola and Cha Khola watershed. Occurs from 795 to 2065 masl.

Ecology: P. annandalei is restricted to springs, springstreams and small to medium-sized hillstreams. Coldwater tolerant, it is relatively abundant in headwaters and upstream stretches. A large form was found at high density in the spring pool of Goshaikunda north of Banepa (1645 masl) surrounded by Pinus roxburghii forest, where the water temperature was stable at around $11^{\circ} \mathrm{C}$; no other bivalve species were recorded at this locale. In another spring pool between Kathmandu University and Shree Khandapur (1490 masl) where the water temperature ranges from $11-15^{\circ} \mathrm{C}$, the eudominant $P$ annandalei occurs sympatrically with several Musculium indicum specimens. Indicator value: Although P.annandale $i$ is widely distributed from unpolluted oligosaprobic zones (Class I) to betamesosaprobic organically polluted zones (Class II and II- 
III), it is the most useful indicator species for drinking water quality assessment. High abundance is only found in water quality Class I and I-II, where P. annandalei reaches its largest size and is often the sole bivalve present. With increasing organic pollution and eutrophication, this species is successively replaced by other Pisidium and Musculium species. In the organically polluted zones of the lower Dhobi Khola and lower Goshaitan Khola near Dhulikhel (1450 masl), which may have water quality Class II-III during spring, a very dense population of sphaeriids can be observed. The dominant taxa are Musculium indicum and Pisidium atkinsonianum, whereas $P$. annandale $i$ is present in only small numbers.

\section{Pisidium (Odhneripisidium) prasongi Kuiper, 1974}

Distribution: Southeast Asia: Thailand (Brandt 1974), South Asia: Nepal. P. prasongi appears to be a more widely distributed species, previously overlooked due to its minute size, or mistaken for immature P. annandalei.

New to the fauna of Nepal: Western region, Kaski District, Pokhara Valley, Sano Tal Khola 0.75 km NW of Khapaudi, 14. 11. + 1. 12. 2004, Khahare Khola near Bhakunde Bagar, 1. 12. 2004, Khanjare KholaW of Sano Tal, 2. 12. 2004, Central region, Kavre District, Mahadevsthan, lower Ashi Khola $0.5 \mathrm{~km}$ SW of Dhaitar, 4. 1.2005. P. prasongi occurs in a very limited altitudinal range between 795 and 815 masl.

Ecology: Recorded from only four streams in Nepal; it is abundant in three localities of the Phewa Tal watershed. Sano Tal Khola is a small cold midhill stream $\left(16^{\circ} \mathrm{C}\right)$ with mixed water from a stream and eutrophic lake. Here P.prasongi occurs in a dense population only in $150 \mathrm{~m}$ long stretch where the stream enters into the wide Harpan-Khola-Phewa Tal floodplain. After the stream mixes with the confluence of Sano Tal, this species is associated with $P$. nevillianum and $P$. clarkeanum. Khahare and Khanjare Khola are two geothermal springstreams $\left(22^{\circ} \mathrm{C}\right)$ with highly diversified benthic invertebrate communities. In the Ashi-Khola watershed only a few specimens of $P$. prasongi were collected together with Musculium indicum and P.nevillianum. Elsewhere this stream is predominantly colonized by P.annandalei.

Indicator value: This species is confined to running water and found in unpolluted to slightly polluted waters of water quality Class I-II to II. P. prasongi replaces P. annandalei below 800 masl. Although P. prasongi is locally abundant, its very limited distribution severely restricts its utility in biological water quality monitoring. Since it is highly localised within Nepal, the occurrence of $P$. prasongi may indicate a unique habitat type within Nepal.

Remarks: P. prasongi is distinguished from the closely allied $P$. annandalei by the following characters: small size, maximum length usually 2.0 to $2.2 \mathrm{~mm}$; thin shell; oval outline; shell surface with fine regular striations and pale periostracum; hinge: anterior and posterior teeth shorter and less swollen than in $P$. annandalei; cardinal teeth C2 and C3 curved.

\section{Pisidium (Odhneripisidium) kuiperi Dance, 1967}

Distribution: India: Sikkim (Dance 1967), Nepal (Nesemann et al. 2001).

Occurence in Nepal: Hitherto, this species was known only from the upper Bhageri Khola at Godawari, southern Kathmandu Valley at 1555 masl. A second locality was recently found $(24,25.10 .2003)$ in the small effluent stream of the Dhumba Tal near Jomson, Mustang District, upper Kali Gandaki watershed.
Ecology: In Mustang P. kuiperi lives abundantly in the fine dark brown mud of slow-running stretches of the stream within acidophilic Juncaceous vegetation. It is accompanied by the Lymnaeids Galba truncatula and Radix hookeri at 2700 masl. Indicator value: Both localities in Nepal are unpolluted waters of water quality Class I-II.

Remarks: In outward appearence live specimens are similar to P.casertanum in size, shape, periostracum color and concentric striations, but differ by in the ligament pit in subgeneric level.

\section{Subgenus Afropisidium Kuiper, 1962}

\section{Pisidium (Afropisidium) ellisi Dance, 1967}

Distribution: Sikkim (India), Nepal.

New to the fauna of Nepal: Kavre District, Banepa, three springstreams to the lower Chandeshwari Khola, $0.8 \mathrm{~km}$ E of Chandeshwari, 15. 1.2005, elevation 1585-1650 masl; Rohini Bhanjyan, springstream of Cha-Khola, 26. 3. 2005, elevation 2065 masl; Kaphalbot, springstream of Ashi-Khola, 7. 4. 2005, elevation 1765 masl.

Ecology: Specimens were collected in small natural cold streams in dense mixed and oak forest. The microhabitat is fine red-brown mud in very shallow pools, where the pea clams are found on the sediment surface. $P$. ellisi usually lives in association with large numbers of $P$.annandalei. Other bivalves found in these waters are P.casertanum and P.atkinsonianum. Additional taxa in this assemblage are the prosobranchia Tricula montana (Pomatiopsidae), two Spring Spire Snails (Erhaia spec. new to the Fauna of Nepal), the Potamid crab Himalayapotamon spec. (sensu Brandis and Sharma 2004) and the Red Algae Batrachospermum moniliforme (Rhodophyceae: Nemaliomales).

Indicator value: Xenosaprobic to oligosaprobic condition of natural oak-forest springs. Water quality Class I. Among all pea clams, P. ellisi is the best indicator of high quality water.

Remarks: P. ellisi can be identified by the following characters: very small shell, length 1.6-1.8 mm (Chandeshwari), $2.0 \mathrm{~mm}$ (Cha-Khola); external ligament prominent and long; the anterior lateral teeth much closer to the cardinal teeth than the posterior laterals; periostracum yellowish-brown with fine concentric striation; most shells dark in appearance having been stained black or brown by the sediment.

\section{Pisidium (Afropisidium) clarkeanum G.\& H. Nevill, 1871}

Distribution: A widely distributed species in South and Southeast Asia, known from India (Prashad 1925, Subba Rao 1989, Nesemann et al. 2003), Nepal (Nesemann et al. 2001), Myanmar, Thailand and Laos (Brandt 1974).

Occurrence in Nepal: Terai in Western, Central and Eastern regions (15 localities): Jhapa, Morang, Sunsari and Rautahat Districts. Midhills, Kavre District: Mahadevsthan, lower Ashi Khola near Kunta (798 masl). Kaski District: Phewa Tal, Sano Tal and Begnas Tal (795 masl), Phusre Khola, Orlan Khola, Khudi Khola, Deura Khola, Chyanladi Khola and Gaduwa Khola. This species is found mostly in warm subtropical lowland waters from 70 to 140 masl. It also occurs at mid-altitudes whenever the local climate and hydrology (geothermal springs of Pokhara Valley) provide suitable microhabitats.

Ecology: In the Gangetic plain and Terai P. clarkeanum is abundant in slowly running streams and rivers; it is occasionally found in the littoral zone along the shores of lakes and large ponds where it prefers lentic areas with a soft muddy bottom. In the mid-altitudinal range, it is very often found sympatrically 
with P.nevillianum, but is usually less abundant than the latter species. By comparison with $P$. nevillianum, P.clarkeanum is restricted mainly to lentic microhabitats, preferring sediments such as mud enriched with detritus or silt.

Indicator value: $P$. clarkeanum is a very good indicator for mesosaprobic conditions with moderate organic pollution. It is dominant in betamesosaprobic to alphamesosaprobic waters with water quality Class II or II-III.

\section{Pisidium (Afropisidium) clarkeanum dhulikhelensis nov. subspec.}

Distribution: Nepal, Kavre District, endemic to the upper Punyamata Valley.

New to the fauna of Nepal: This is considered to be a distinct subspecies of $P$. clarkeanum. It is confined to temporary waterbodies of the Punyamata between Panauti and Banepa. P. clarkeanum dhulikhelensis nov. subspec. is known only from elevations between 1430 and 1495 masl.

Ecology: This is a highly specialized species able to exploit the temporary aquatic habitats of paddy fields where it may occur at very high densities and is often the sole bivalve species present, although it may occur with Musculium goshaitanensis nov. spec. Other bivalves cannot survive permanently in such habitats, although they are occasionally carried into paddy fields with flood waters. P.clarkeanum dhulikhelensis nov. subspec. lives in association with the fairy moss Azolla pinnata var. africana. Life span: Activity period June to October. Diapausis of juveniles in soil depth of $\geq 50 \mathrm{~cm}$ from end of October to mid-June.

Indicator value: The presence of Pisidium clarkeanum dhulikhelensis indicates a fairly good oxygen level in water and sediment, equivalent to a betamesosaprobic situation of water quality Class II.

Description and differential diagnosis: $P$. clarkeanum dhulikhelensis nov. subspec. can be distinguished from P. clarkeanum sensu stricto by the following characters: thin tumid shell with colorless pale periostracum; oval outline (subtrigonal in P. clarkeanum), prominent umbones always with distinct caps, more central than in P.clarkeanum hinge more elongated with thin teeth; P2 always curved, C2 always prominent and closer to a 2 than in the nominate subspecies.

\section{Pisidium (Afropisidium) nevillianum Theobald, 1876}

Distribution: South and Southeast Asia: India (Prashad 1925, Subba Rao 1989, Nesemann et al. 2003), Bangladesh (Brandt 1974, Subba Rao 1989), Nepal (Nesemann et al. 2001), Thailand (Brandt 1974).

Occurrence in Nepal: Terai in Central and Eastern regions (20 localities). Adittional records from Terai: Bishazari Tal (coll. P. B. Budha, TU Kirtipur), from midhills in Central region (Kavre
TABLE 1. Zoogeographical comparison of different Eurasian Sphaeriidae fauna

\begin{tabular}{|c|c|c|c|}
\hline \multirow[t]{2}{*}{ Subgenus } & \multicolumn{3}{|c|}{ Species/subspecies } \\
\hline & (West-) Palaearctis & Nepal & Thailand \\
\hline Pisidium s. str. & amnicum & & \\
\hline \multirow{12}{*}{ Euglesa } & \multicolumn{3}{|c|}{ casertanum } \\
\hline & cas. ponderosum & atkinsonianum & \\
\hline & globulare & & \\
\hline & henslowanum & & \\
\hline & supinum & & \\
\hline & milium & & \\
\hline & nitidum & & \\
\hline & pulchellum & & \\
\hline & personatum & & \\
\hline & lilljeborgi & & \\
\hline & pseudosphaerium & & \\
\hline & obtusale & & \\
\hline \multirow[t]{2}{*}{ Neopisidium } & moitessierianum & & \\
\hline & conventus & & \\
\hline \multirow[t]{3}{*}{ Odhneripisidium } & tenuilineatum & \multicolumn{2}{|l|}{ annandalei } \\
\hline & stewarti (subfossil) & \multicolumn{2}{|l|}{ prasongi } \\
\hline & & kuiperi & sumatranum \\
\hline \multirow[t]{4}{*}{ Afropisidium } & & ellisi & \\
\hline & & \multicolumn{2}{|l|}{ nevillianum } \\
\hline & & \multicolumn{2}{|l|}{ clarkeanum } \\
\hline & & cl. dhulikhelensis & javanum \\
\hline \multirow[t]{2}{*}{ Musculium } & lacustre & indicum & \\
\hline & transversum & goshaitanensis & \\
\hline \multirow[t]{2}{*}{ Sphaerium } & corneum & & \\
\hline & scaldianum & & \\
\hline Sphaeriastrum & rivicola & & \\
\hline Cyrenastrum & solidum & & \\
\hline \multirow[t]{2}{*}{ Nucleocyclas } & nucleus & & \\
\hline & ovale & & \\
\hline TAXA & 25 & 11 & 7 \\
\hline
\end{tabular}

District): Cha Khola, Ashi Khola. Midhills in Western region (Kaski District): Phewa Tal, Begnas Tal, Sano Tal, Gaduwa Tal, Orlan Khola, Khudi Khola, Deura Khola, Chyanladi Khola, Gaduwa Khola and Tal Khola. P. nevillianum is found at elevations between 75 and 920 masl.

Ecology: This is a subtropical species requiring high water temperatures during the summer and monsoon; it also needs organic matter and detritus to flourish. P. nevillianum is very 
common across a wide range of streams and small rivers and is a dominant species in larger lakes in the midhills. High densities were observed in agricultural irrigation channels, where $P$. nevillianum is usually accompanied by $P$. annandalei. Unlike P. clarkeanum, P. nevillianum is predominantly found in lotic microhabitats. It prefers sediments with a mud and sand mixture or even pure sand.

Indicator value: $P$. nevillianum lives mainly under betamesosaprobic conditions. Due to its wide range and abundance, it is a very useful indicator for water quality class II. It also occurs in slightly polluted midhill irrigation channels (together with Odhneripisidium species) of Class I-II and occasionally in Terai in critically polluted zones of Class II-III, wherever the water current provides enough oxygen.

\section{Zoogeographical comments}

The Eurasian continent is sharply divided by the Alpine/ Himalayan mountain range system (Banarescu 1992) into the northern Palaearctic and southern Oriental region. The faunal composition of Sphaeriidae in the Nepalese mid-altitudinal range is a mixture of both regions and can be described as a transitional zone, although all running waters are part of the Gangetic watershed. Afropisidium originates from the Oriental region, whereas Odhneripisidium is centred in Central Asia. From the Palaearctic region Musculium has invaded the southern Himalayan midhills. The predominantly palaearctic Euglesa, although highly diverse, is poorly represented in Nepal. The ecological niches of European Euglesa are partially occupied in Nepal by Odhneripisidium, Afropisidium and Musculium. Two pea clams P. (O.) kuiperi, P. (A.) ellisi are endemic to the Central Himalayan region in Nepal and Sikkim. The only widespread species in Europe and Asia is Pisidium casertanum. In contrast to the temperate zones of the Palaearctic, where P. casertanum is very common, it is rare in South and Southeast Asia, where it is limited to a few cold water habitats. Two pea clams $M$. goshaitanensis $\mathrm{n}$. sp. and $P$. (A.) clarkeanum dhulikhelensis $\mathrm{n}$. subspec. are endemic to Punyamata Valley, obviously evolved with an ancient pleistocene lake.

\section{References}

Banarescu P. 1992.Distribution and dispersal of freshwater animals in NorthAmerica and Eurasia. In: Banarescu P (eds), Zoogeography of Fresh Waters, Vol 2. Aula-Verlag, Wiesbaden, Germany. p 519-1091

Brandis D and S Sharma. 2004. Biodiversity and biogeography of Himalayan freshwater crabs. In: International Conference on the Great Himalayas: Climate, Health, Ecology, Management and Conservation, 2004 Jan 12-15, Kathmandu, Nepal. Organised by Kathmandu University. p 55-65

Brandt RAM. 1974. The non-marine aquatic Mollusca of Thailand. Archiv für Molluskenkunde 105(1-4): 1-423

Clarke AH. 1981. The Freshwater Molluscs of Canada. Ottawa: National Museum of Natural Sciences. $446 \mathrm{p}$

Dance SP. 1967. Pisidium collected by the 1924 Mount Everest Expedition, with descriptions of two new species (Bivalvia: Sphaeriidae). Journal of Conchlogy London 26(3): 177-180

Nesemann H, A Korniushin, S Khanal and S Sharma. 2001. Molluscs of the families Sphaeriidae and Corbiculidae (Bivalvia: Veneroidea) of Nepal (Himalayan mid-mountains and Terai), their anatomy and affinities. Acta Conchyliorum 4: 1-33

Nesemann H, G Sharma and RK Sinha. 2003. The Bivalvia species of the Ganga River and adjacent stagnant water bodies in Patna (Bihar, India) with special reference on Unionacea. Acta Conchyliorum 7: 1-43

Nevill G and H Nevill. 1871. Descriptions of New Mollusca from the Eastern Regions. Journal of the Asiatic Society of Bengal 40: 1-11

Prashad B. 1922. Observations on the invertebrate fauna of the Kumaon Lakes III. The Freshwater Mollusca. Records of the Indian Museum 24: 11-17

Prashad B. 1925. Notes on lamellibranch in the Indian Museum. 6. Indian species of the genus Pisidium. Records of the Indian Museum 27: 405-422 pl 7+8

Sharma S. 1996. Biological assessment of water quality in the rivers of Nepal [thesis]. Wien: Universität für Bodenkultur. 257+cxxxiv p

Subba Rao NV. 1989. Freshwater Molluscs of India. Calcutta: Zoological Survey of India. xxiii +289 p

Theobald W. 1876. Descriptions of the new land and freshwater shells from India and Burma. Journal of the Asiaic Society of Bengal 45(2): 184-189

Zeissler H. 1971. Die Muschel Pisidium. Bestimmungstabelle für die mitteleuropäischen Sphaeriaceae. Limnologica 8(2): 453-503

\section{Plates on the next pages}




\section{RESEARCH PAPERS}
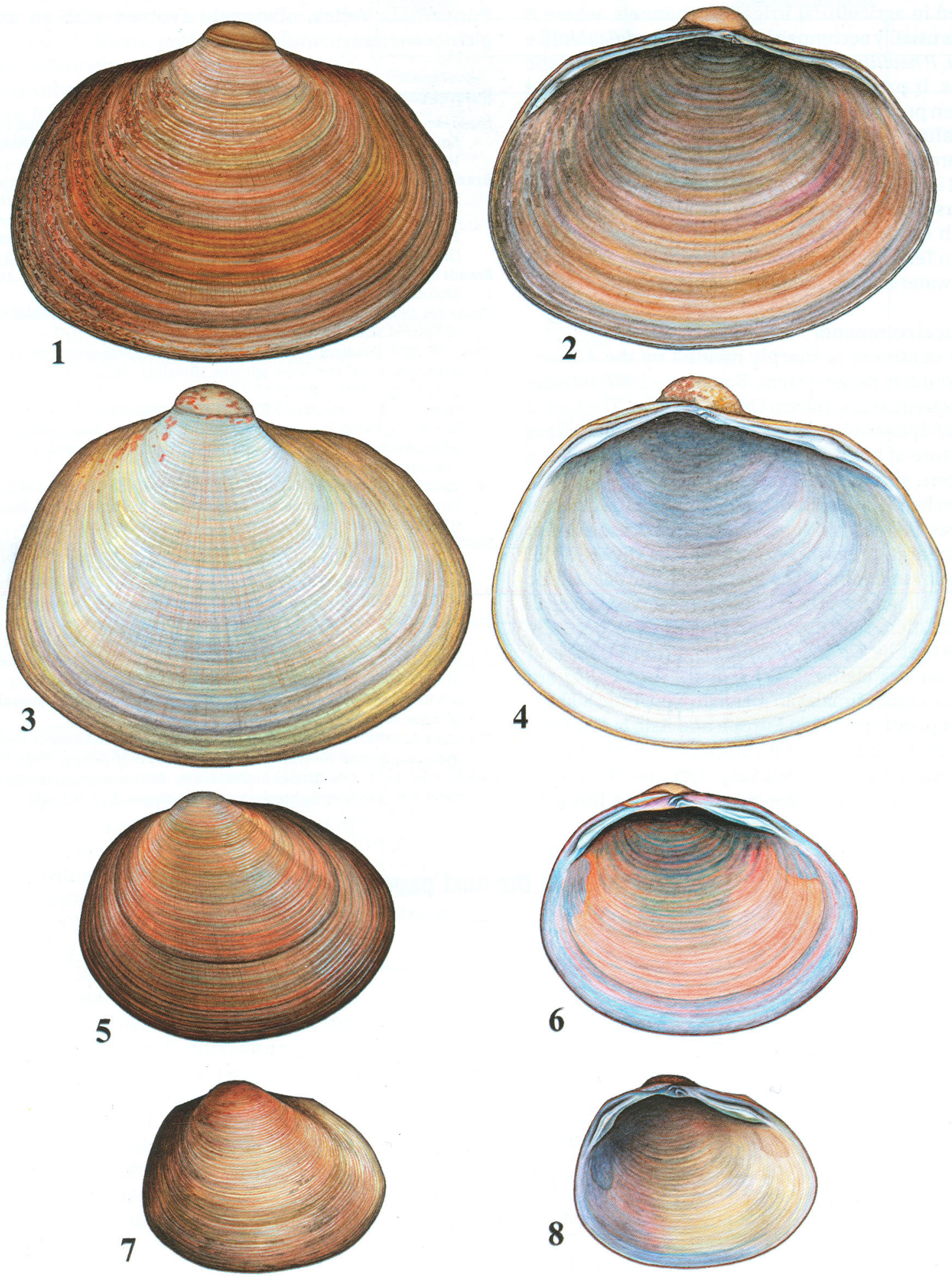

\section{PLATE I. Musculium and Euglesa}

1 and 2: Musculium goshaitanensis, Kavre, Dhulikhel, Paddy-field near Dhobi-Khola, length $10.3 \mathrm{~mm}$, Holotype, Natural History Museum Vienna, Mollusca Collection No. 103317

3 and 4: Musculium indicum, Kavre, Dhulikhel, Dhobi-Khola, length $9.6 \mathrm{~mm}$, Natural History Museum Vienna, Mollusca Collection No. 103311

5 and 6: Pisidium (Euglesa) atkinsonianum, Kavre, Dhulikhel, Dhobi-Khola, length $5.8 \mathrm{~mm}$, Natural History Museum Vienna, Mollusca Collection No. 103306 7 and 8: Pisidium (Euglesa) casertanum, Kavre, Banepa, Chandeshwari Khola watershed, small spring-stream, length 3.8 mm, Natural History Museum Vienna, Mollusca Collection No. 103304

Note: All figures are in the same scale. 


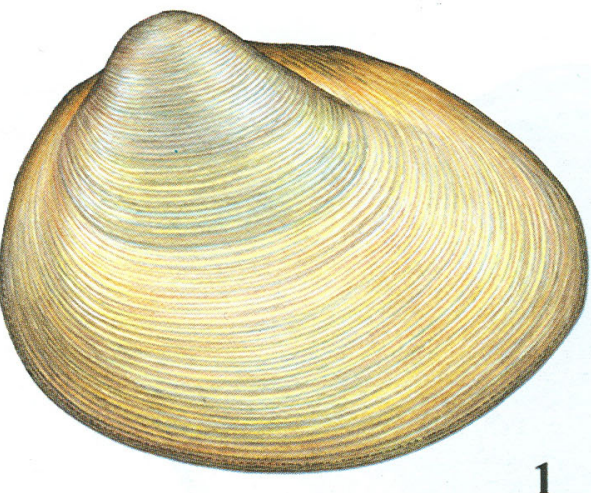

1

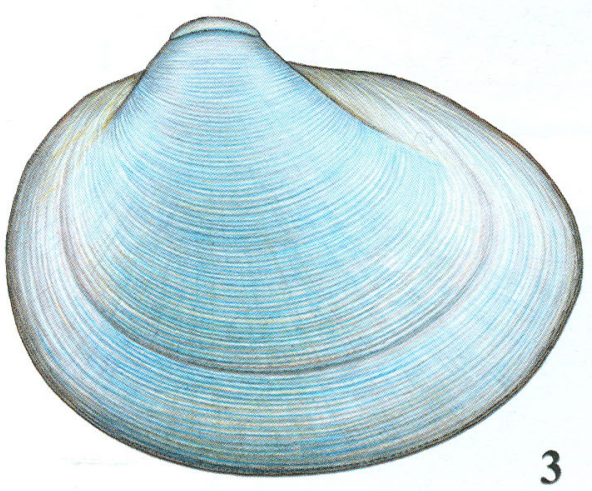

3
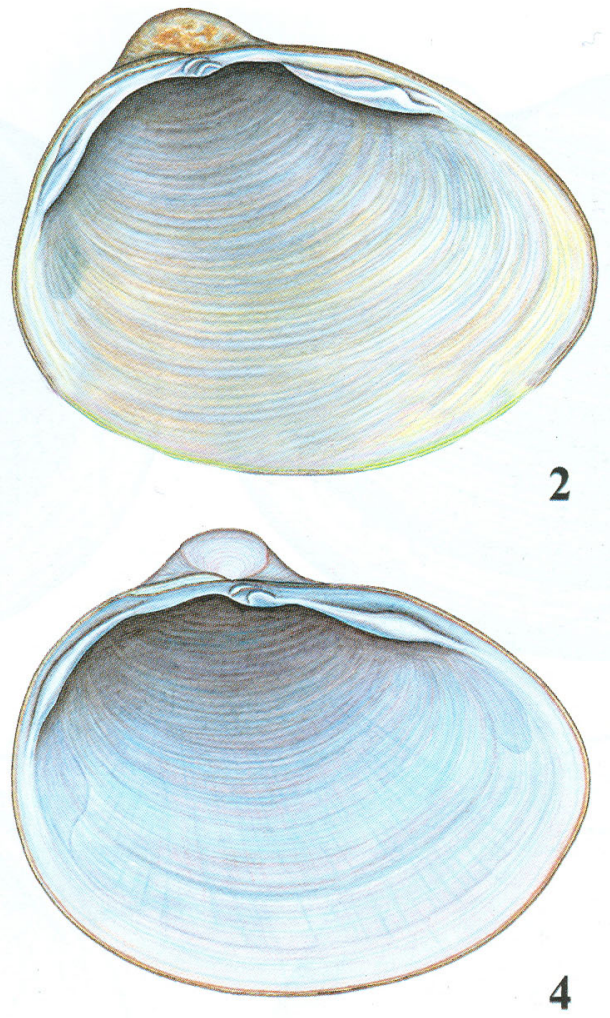

4

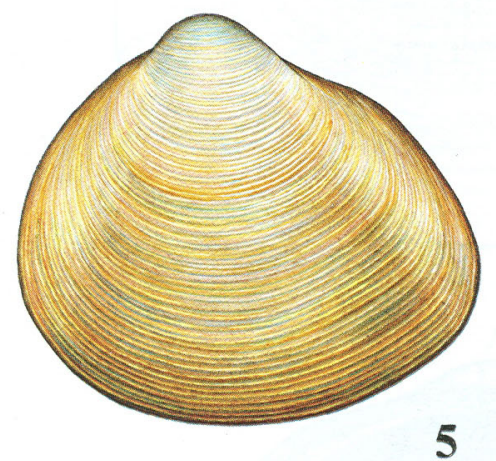

5

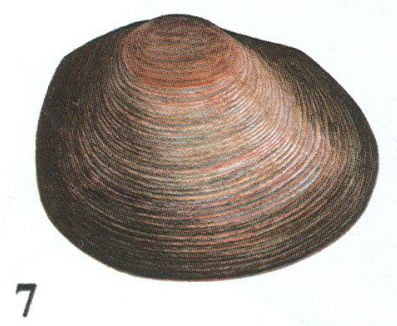

8
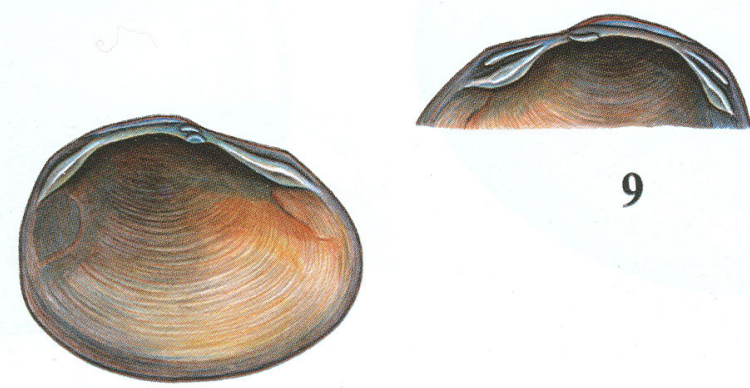

9

\section{PLATE II. Afropisidium}

1 and 2: Pisidium (Afropisidium) clarkeanum sensu stricto, Kavre, Asi-Khola near Kunta, length $4.7 \mathrm{~mm}$, Natural History Museum Vienna, Mollusca Collection No. 103305

3 and 4: Pisidium (Afropisidium) clarkeanum dhulikhelensis, Kavre, Dhulikhel, Paddy-field near Dhobi-Khola, length 4.7 mm, Holotype, Natural History Museum Vienna, Mollusca Collection No. 103313

5 and 6: Pisidium (Afropisidium) nevillianum, Kavre, Asi-Khola near Kunta, length 3.9 mm Natural History Museum Vienna, Mollusca Collection No. 103307 7-9: Pisidium (Afropisidium) ellisi, Kavre, Banepa, Chandeshwari Khola watershed, small spring-stream, length 2.0 mm, Natural History Museum Vienna, Mollusca Collection No. 103308

Note: All figures are in the same scale. 


\section{RESEARCH PAPERS}
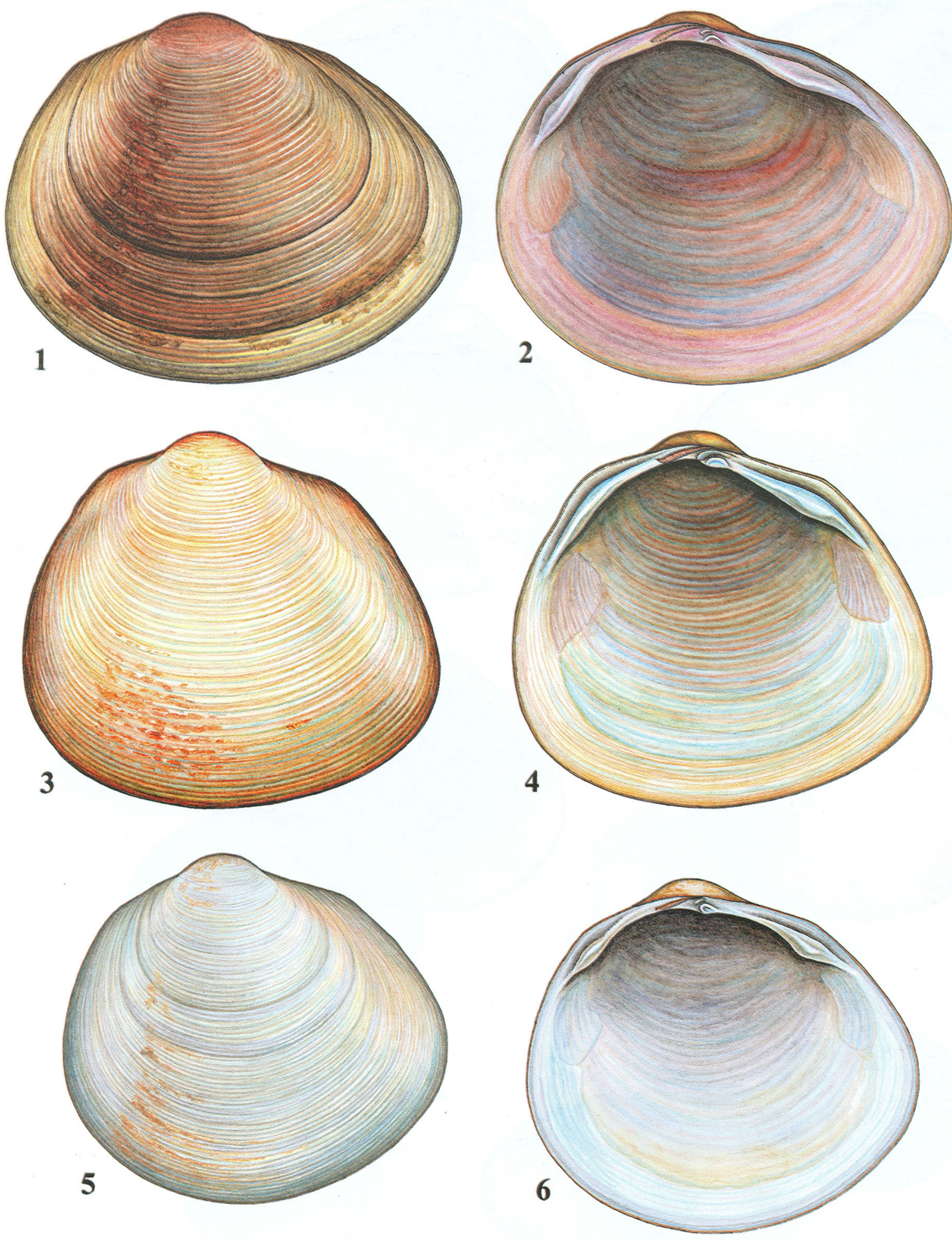

\section{PLATE III. Odhneripisidium}

1 and 2: Pisidium (Odhneripisidium) kuiperi, Mustang, Dhumba Tal effluent near Jomson, length $3.6 \mathrm{~mm}$, Natural History Museum Vienna, Mollusca Collection No. 103309

3 and 4: Pisidium (Odhneripisidium) annandalei, Kavre, Dhumba Tal Asi-Khola $2.5 \mathrm{~km}$ upstream of Dhaitar, length $2.5 \mathrm{~mm}$, Natural History Museum Vienna, Mollusca Collection No. 103310

5 and 6: Pisidium (Odhneripisidium) prasongi, Kaski, Sano Tal-Khola near Phewa Tal, length $2.1 \mathrm{~mm}$, Natural History Museum Vienna, Mollusca Collection No. 103303.

Note: All figures are in the same scale. 

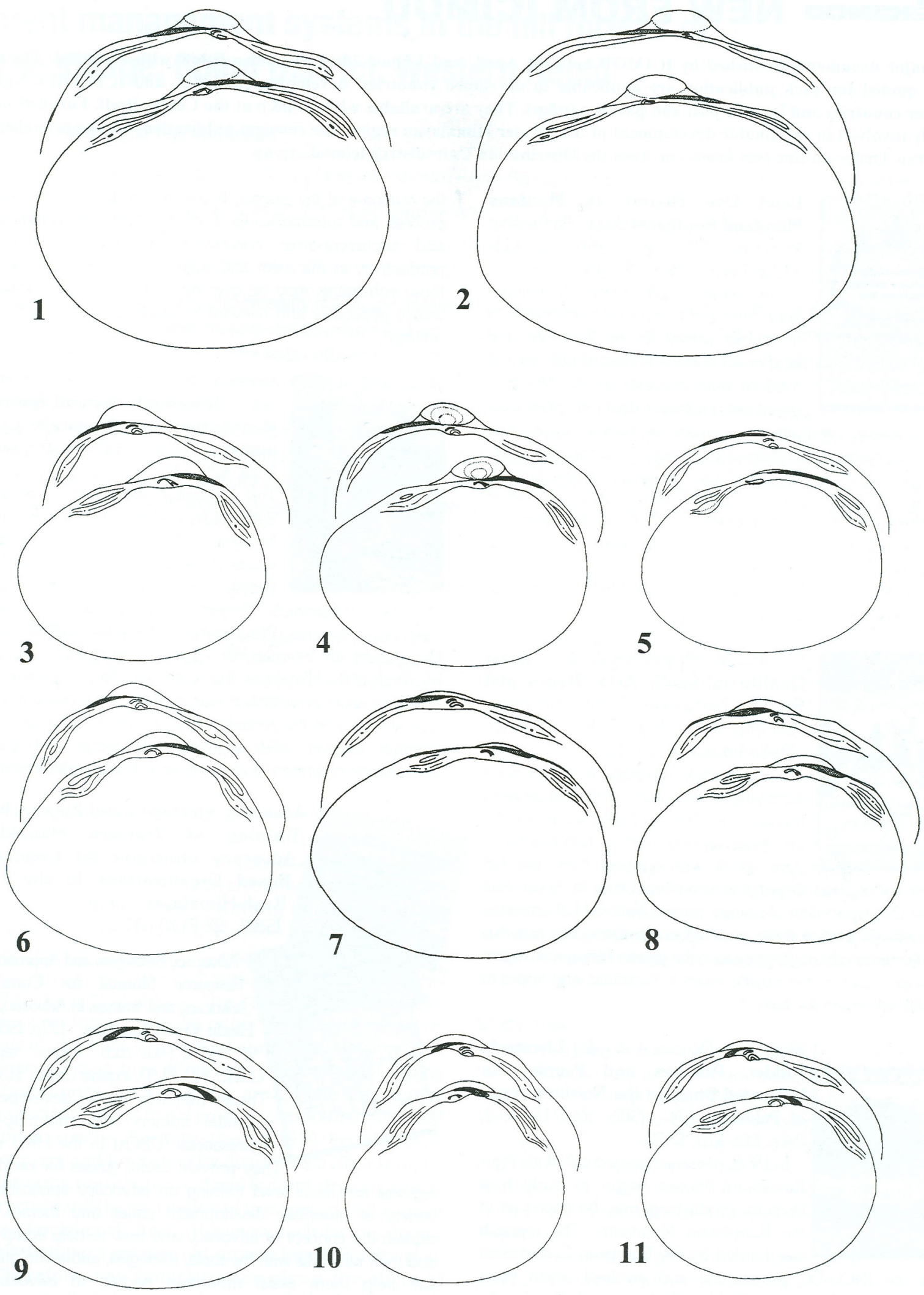

\section{PLATE IV. Sphaeriidae characters of hinge}

1: Musculium indicum

2: Musculium goshaitanensis

3: Pisidium clarkeanum
4: Pisidium clarkeanum dhulikhelensis

5: Pisidium ellisi

6: Pisidium nevillianum

7: Pisidium atkinsonianum
8: Pisidium casertanum

9: Pisidium kuiperi

10: Pisidium annandalei

11: Pisidium prasongi

Note: Figures not in the same scale. 